\title{
Neuroendocrine Management of Mental Peace: Prevention is Better than Cure
}

\author{
Tabassum Zafar*, Vinoy K Shrivastava \\ Laboratory of Endocrinology, Department of Biosciences, Barkatullah University, India
}

Submission: January 11, 2018; Published: March 15, 2018

*Corresponding author: Tabassum Zafar, Laboratory of Endocrinology, Department of Biosciences, Barkatullah University, Bhopal (M.P.), India, Email: tztabassumzafar@gmail.com

\section{Opinion}

In the fast pacing 21st century, where scientific and medical advancements are at their peak, still there are many challenges to overcome for the mankind. With each passing day, we are growing faster than fast to changeover our status developed from developing, but in between somewhere the most neglected part is physical and mental health. We are now standing on an edge where on one side the first humanoid robot "Sophia" has become a legal citizen of country and on the other side millions of human beings facing malnutrition, stress and psychological illness worldwide [1,2]. Mental peace and pleasure have become most desired but less achieved targets nowadays. Stress is the simplest type of psychological illness, but it remains the root cause of many neurological and physiological disorders once left unmanaged $[3,4]$.

Mental peace is actually a condition in which all neurotransmitters of the vital system work in proper coordination with endocrine and other peripheral physiological systems of the body. The relationship between physical and mental health is reciprocal. Mental health is a result of various biochemical co-ordinations between hormones, enzymes and metabolites, which are essential for physical health too. Cortisol, endorphins/enkephalins, dopamine, oxytocin, endocannabinoids, acetylcholine, norepinephrine, epinephrine, glutamate, and histamine are few most effective chemicals, which play important role in achieving healthy nervous system [5,6]. Apart from all available resources and technologies for identification, management and diagnosis of neurological disorders, still it is not possible to overcome each and every disorder. It is rather a better option for society to manage the stress and achieve mental peace to avoid progression of severe neurological implications.

Achieving mental health helps the body to balance the levels of melatonin, which boosts good sleep to balance circadian rhythms. Mental peace enhances the production of serotonin "the pleasure chemical" which initiates the sense of peace security, satisfaction and contentment. Mental peace improves the circulation of growth hormones for better management of vitality, vigor and physical strength. Mental peace helps the immune system to respond better against any of the available infection. Mental peace enhances the production of endorphins during various physical activities to maintain "the feel good factor". Mental peace achievement enhances the production of gamma amino butyric acid (GABA), which calms down the nervous system and brain. Mental peace is the source requirement for longevity as mental peace also enhances the production of dehydroepiandrosterone hormone (DHEA). Significant reduction in cortisol levels followed by the serotonin increment achieves the inner feeling of happiness to signal the brain that everything is favorable and pleasant $[7,8]$.

The next biggest challenge among health industry is not to search cure for newly discovered diseases but to maintain the health management by natural means. In author's perspective management of mental peace has a strong health perspective behind, which is ignored very much nowadays, as everyone is busy enough in rat race to achieve physical materialistic goals at the cost of own health. In my opinion the use of synthetic molecules to treat neurological disorders will reduce significantly if the natural cycle of happiness and peace is restored, by preventing the imbalance of mental peace. Authors appreciate and strongly recommend the concept of prevention rather than cure. "Prevention is better than cure" is not just an ancient proverb but also an insight of health to maintain biochemical management of sociopsychological health issues.

\section{References}

1. Sophia the robot.

2. World Health Organization (2006) Nurological disorders and public health chalenges.World Health Organization. WHO Press, Switzerland.

3. Global Nutrition report.

4. Blakeslee S. Humanity? Maybe it's in the wiring. New York Times.

5. Shapiro LE, Insel TR (1990) Infants response to social separation reflects adult differences in affinitive behavior, a comparative developmental study in prairie and mountain voles. Development Psychobiol 23: 375-393. 
6. McBride RS (2011) Peace power and a sound mind. Balboa Press, Bloomington, USA.

7. Vaillant GE (2011) The Neuroendocrine System and Stress, Emotions, Thoughts and Feelings. Mens Sana Monogr 9(1): 113-128.
8. Linkowski P (2003) Neuroendocrine profiles in mood disorders. Int J Neuropsychopharmacol. 6(2): 191-197.

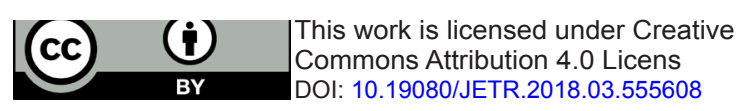

Your next submission with Juniper Publishers will reach you the below assets

- Quality Editorial service

- Swift Peer Review

- Reprints availability

- E-prints Service

- Manuscript Podcast for convenient understanding

- Global attainment for your research

- Manuscript accessibility in different formats ( Pdf, E-pub, Full Text, Audio)

- Unceasing customer service

Track the below URL for one-step submission https://juniperpublishers.com/online-submission.php 